\title{
Performance Evaluation of Dry Season Okra under Sawdust and Trash Mulch Cover Treatments in Southwestern Nigeria
}

\author{
Oladipo Isaac Olaposi ${ }^{1^{*}}$, Adewumi Johnson Kayode ${ }^{2}$, Dairo Olawale Usman², \\ Adejuyigbe Samuel Babatope $^{3}$, Ajayi Ebenezer Ayodele ${ }^{4}$ \\ ${ }^{1}$ The Federal Polytechnic Department of Agricultural and Bioenvironmental Engineering PMB, Ado Ekiti, Nigeria; ${ }^{2}$ Department of \\ Agricultural Engineering, Federal University of Agriculture, Abeokuta, Nigeria; ${ }^{3}$ Department of Mechanical Engineering, Federal \\ University of Agriculture, Abeokuta, Nigeria; ${ }^{4}$ Department of Agricultural Engineering, Federal University of Technology, Akure, \\ Nigeria. \\ Email: *oladipoisaac@gmail.com
}

Received June $20^{\text {th }}$, 2013; revised July $20^{\text {th }}$, 2013; accepted July $27^{\text {th }}, 2013$

Copyright (c) 2013 Oladipo Isaac Olaposi et al. This is an open access article distributed under the Creative Commons Attribution License, which permits unrestricted use, distribution, and reproduction in any medium, provided the original work is properly cited.

\begin{abstract}
This paper reports the experimental investigation of the agronomic performance of okra under various quantities of both sawdust and trash mulches. The location of the field was the research farmland of the Federal Polytechnic Ado Ekiti Nigeria; Lat $6^{\circ} \mathrm{N}$ and Long $16^{\circ} \mathrm{E}$. The experimental design used was complete randomized design with 6 treatments on both specimens. The experiments were repeated the following year on the same plot but with transposed plot allocation. Soil moisture loss from uncovered plot was with the highest value dropping to less than 2 per cent. It was followed by that of trash plot and the lowest loss was on sawdust mulched plot. The number of leave formed by okra on sawdust, trash and no mulch plots was 43, 36 and 27 respectively while maximum girth diameter was $37 \mathrm{~mm}$ in both trash and sawdust covered plots but okra plant on control plot attained only $26 \mathrm{~mm}$ diameter. Fruit yield were almost similar to trash and sawdust mulched okra having 7.5 and 7.6 Tonnes/Ha respectively while control plot recorded 5.2 Tonnes/Ha. The ash content of dry matter of sawdust, trash and no mulched plants was $0.25,0.20$ and $0.17 \mathrm{~kg}$ respectively. It was concluded that sawdust could perform as much as the traditional trash materials commonly used in Southwestern Nigeria. Also, sawdust was a good material for conserving soil moisture.
\end{abstract}

Keywords: Evapotranspiration; Carbon Capture; Agronomic Development; Soil Moisture; Climate Change

\section{Introduction}

Soil moisture is an important factor for plant growth. Most vegetable crops can tolerate very low soil moisture, but will suffer permanent wilting that may result into collapse of the tissue cells and final death if further dryness persists [1,2]. In Southwestern Nigeria, it is traditional to target vegetable production at the wet rainy season between April and October when water supply to the crop is almost guaranteed by rainfall. This part of the country records between 1500 - $2500 \mathrm{~mm}$ of rainfall annually [3, 4]. This amount is far more than the crop water requirements (CWR) of most vegetable crops grown in this region [5]. The practice before now is that most farmers go for production at the time when water is available natural-

\footnotetext{
"Corresponding author.
}

ly (rainfed). As such the product often comes out around the same time causing market glut at the peak season. The economic return is low and poor [6-8]. Wastage due to lack of storage was up to 50 per cent of vegetable and perishable products produced in the last 5 years $[9,10]$.

As the food security awareness campaign grew in the recent time, the farmers were drawn to the need to adjust their farming schedule in such a way to avoid crowded supply where the products will arrive at the market at the same time. Also to maximize food production, the UNDP came up and support the dry-season farming with direct intervention fund to the tune of 35 Million US Dollars $[11,12]$. Experiences have shown that the farmers were confronted with high evapotranspiration (ET) rate in Southwestern Nigeria. To arrest this situation there was a need to search out methods that are easily accessible 
sustainable and affordable. Mulching is one of those methods that had been used to secure soil moisture, reduce excessive ET and soil temperature [13-15].

Materials used for mulching varies from organic and inorganic materials; dry leaves, crop residue, farm wastes, grasses and trash were among the common ones. These materials have one advantage or the other; With low cost locally available, they contribute to soil fertility eventually, while inorganic materials may attract a little cost, but they are durable and efficient in performance $[16,17]$.

In Southwestern Nigeria the average value of ET is between 0.3 and 0.7 [18] Sawdust is an organic material that has most of the qualities of mulching material, but is not commonly used in the region. Despite its availability almost at no cost, as a matter of fact it is currently constituting great nuisance to the environment, occupying over 20 per cent of the total space in most sawmills and it is growing at an unprecedented rate of 10 per cent per annum, it may become a major waste challenge in the nearest future [19-21]. The method used for disposing sawdust at present is the open air burning system, a practice that generates and emits several metric Tonnes of obnoxious gases into the atmosphere [22-25]. The good news is that sawdust had the potential of locking up carbon if proper disposal and usage is identified [26-29]. It is easily degradable if predisposed to termite infestation on the field [26]. Sawdust unlike other mulching material is highly hygroscopic. It tends to hold on to water that moves through it and as such increases it humidity, a property that acts as carpet on soil surface if used as mulch and reducing evaporation rate from the soil. Sawdust comprises of particles of spindle and platy shape. This property is favourable for wider coverage and greater ability to prevent evaporation from the soil [27].

The aim of this research is to explore the avenues where sawdust could be used on the farmland so as to improve the economic return of agricultural practice. It also aimed to find alternative use for sawdust in order to proffer solution to the problem of waste accumulation in sawmills in Southwestern Nigeria. This way, the space presently occupied by sawdust could be salvaged for a better economic use and reduce the amount of gas released into the atmosphere through open air burning of sawdust.

\section{Materials and Methods}

The site of the experiment was the farm practice site of the Federal Polytechnic Ado Ekiti S. W. Nigeria located around Lat $6^{\circ} \mathrm{N}$ and Long $16^{\circ} \mathrm{E}$. The size of the plot was $20 \mathrm{~m} \times 20 \mathrm{~m}$ partitioned into 6 rows and 6 columns. The sawdust mulch treatments were assigned to the plots randomly without bias and without replicate on neither the row nor the column arrays (Table 1). The trash mulched plot was located directly beside that of sawdust
Table 1. Experimental plot design for okra under sawdust and trash mulch treatment.

$$
\begin{gathered}
\mathrm{T} 0=0 \mathrm{~kg} \mathrm{~A}=(\text { No mulch cover = control }) \\
\mathrm{T} 5=\mathrm{B}=5 \mathrm{~kg} \text { on } 25 \mathrm{~m}^{2}=20 \text { Tonne } / \mathrm{Ha} \\
\mathrm{T} 10=\mathrm{C}=10 \mathrm{~kg}=40 \text { Tonne} / \mathrm{Ha} \\
\mathrm{T} 15=\mathrm{D}=15 \mathrm{~kg}=60 \text { Tonne } / \mathrm{Ha} \\
\mathrm{T} 20=\mathrm{E}=20 \mathrm{~kg}=80 \mathrm{Tonne} / \mathrm{Ha} \\
\mathrm{T} 25=\mathrm{F}=25 \mathrm{~kg}=100 \text { Tonne} / \mathrm{Ha}
\end{gathered}
$$

with a horizontal transpose of the column of sawdust plot that produced its mirror image. Both fields were irrigated uniformly to field capacity using sprinkler irrigation system and the return time is dictated by the sight of the slightest sign of water stress on any okra plant. All cultural practices normally carried out on a farm were observed throughout the growing period of the crop.

Soil moisture content was measured on daily basis for the period covered by the experiment. Records were taken of the vegetative development and the actual fruit yield of the crop. The experiment was repeated on the same plot after a year with the allocation of treatments achieved by row-column transpose of the first allocation.

\section{Results and Discussion}

Figure 1 presents the soil moisture conservation under various quantities of sawdust mulch and the notation are as shown in the note below:

Note: $\mathrm{T} 0=0 \mathrm{~kg}, \mathrm{~T} 5=20$ Tonne/Ha, $\mathrm{T} 10=40$ Tonne/ Ha, T15 $=60$ Tonne/Ha, T20 $=80$ Tonne $/$ Ha, T25 $=100$ Tonne/Ha.

The rate of mositure loss was found to be greatest in the plot without mulch cover and lowset in plot with 100 Tonne/Ha mulch cover. This rate showed a general reciprocal of the quantity of mulch cover. The trend recorded in trash mulch treatment was similar to that of sawdust treatment as shown in Figure 2. This is a confirmation that sawdust could be used as mulching material in dry season vegetable production just like trash in Southwestern Nigeria.

Figure 3 presents the quantity of leaves formed over the growth period of okra under mulch cover treatments. Leaves formation was found to be best under sawdust mulch cover with about 45 leaves on most of the crops while trash mulched okra had about 40 leaves on the average. The lowset number of leaves was found on plot without mulch cover. This is expected because there was excessive evapotransiration rate which resulted in water stress. Most of the sign of wilting, used as a signal for irrigation, were seen on the plot without mulch. Again, this observation is a supporting evidence to show that sawdust is as good as trash if not better a mulching mate- 


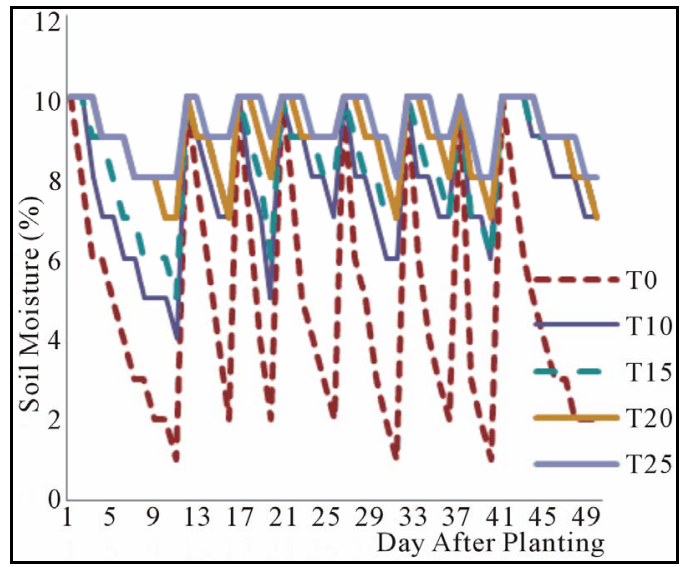

Figure 1. Soil moisture conservation under various quantities of sawdust mulch.

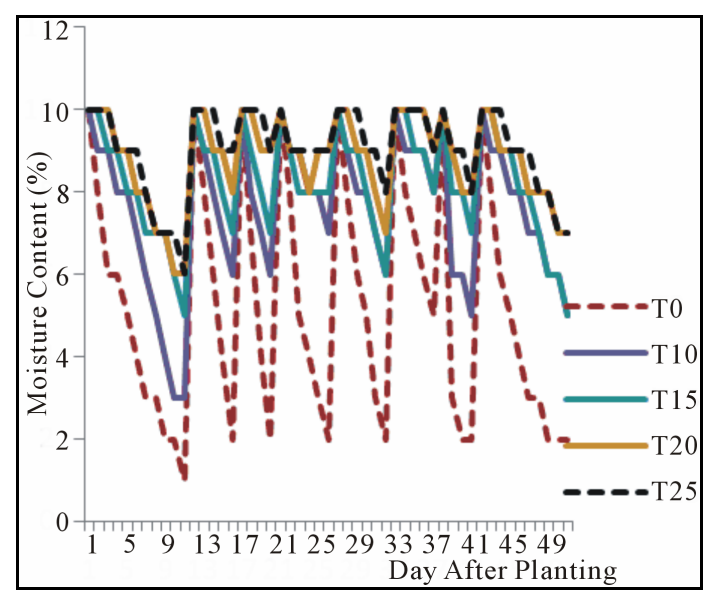

Figure 2. Soil moisture conservation under various quantities of trash mulch.

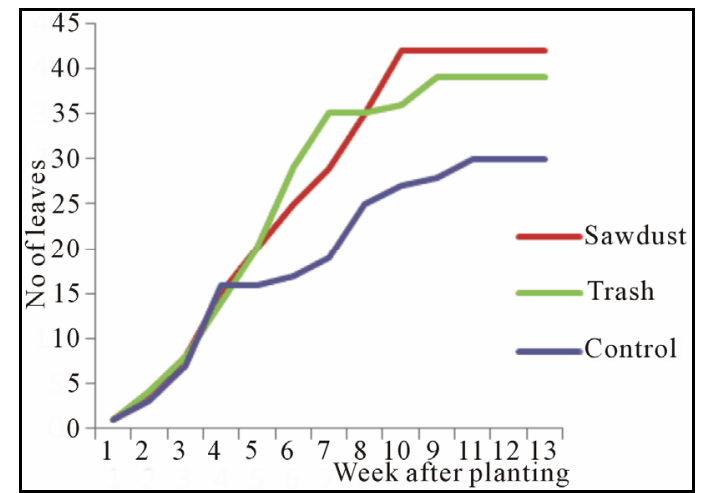

Figure 3. Leave formation of okra under different mulch cover.

rial in dry season vegetable production in Southwestern Nigeria.

Figure 4 shows the height of okra grown under mulch cover treatments. The graphs of sawdust and mulch covered plots were quite close together throughout their flow trends. This is interpreted as a similarity in the performance of okra under both mulch cover during the period of this experiment. The performance of height of plant development was not as good in plots without mulch cover. This again confirms that sawdust is as good as the conventional trash mulch material for dry season vegeetable production in Southwestern Nigeria.

Figure 5 presents the stem girth development of okra grown under sawdust and trash mulch cover treatments. The crop stopped further increase in girth growth after attaining a maximum of $35 \mathrm{~mm}$ diameter on plot without mulch. Whereas girth growth moved as far as $32 \mathrm{~mm}$ in diameter in plants grown under sawdust and trash mulch cover treatments. Girth development in both sawdust and trash mulch cover were quite similar and close. This is to confirm the suitability of sawdust as mulching material just as trash in dry season vegetable production in Southwestern Nigeria.

Much of the performances recorded in vegetative performance of okra were reflected in the eventual fruit yield. Table 2 shows the yield of okra fruits on plots under sawdust and trash mulch cover treatments as well as plots without mulch cover. Fruit yield performed best in sawdust mulched plot attaining about 7.6 Tonnes/Ha on the $12^{\text {th }}$ week after planting and later dropped to

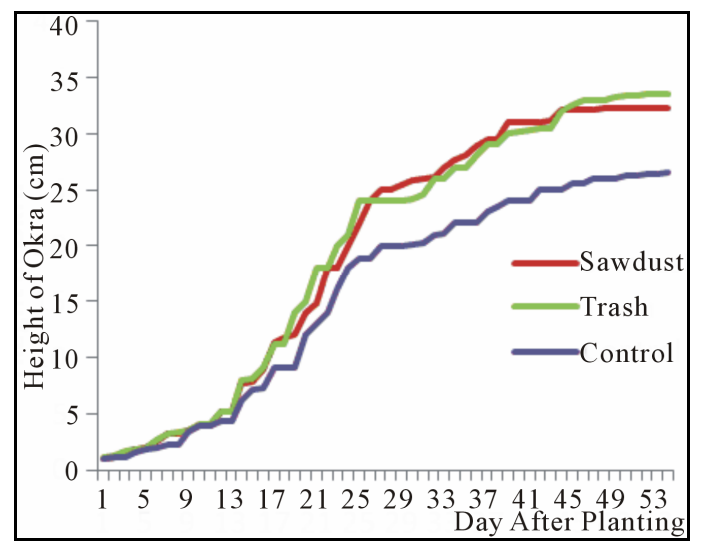

Figure 4. Hieght of okra plant under different mulch cover.

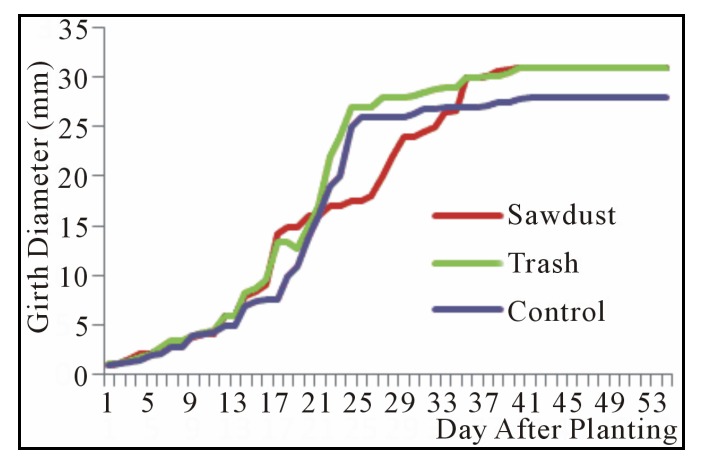

Figure 5. Girth diameter of okra plant under different mulch cover. 
Table 2. Fruit yield of dry season okra production under different mulch cover treatments.

\begin{tabular}{cccc}
\hline \multirow{2}{*}{$\begin{array}{c}\text { Week After } \\
\text { Planting }\end{array}$} & \multicolumn{3}{c}{ Fruit Yield in Tonne/Ha } \\
\cline { 2 - 4 } & Sawdust Mulch & Trash Mulch & Control \\
\hline 9 & 4.2 & 4.0 & 3.2 \\
10 & 5.4 & 4.9 & 3.5 \\
11 & 7.5 & 6.8 & 5.2 \\
12 & 7.6 & 7.4 & 4.8 \\
13 & 7.4 & 7.5 & 1.9 \\
14 & 7.3 & 7.2 & 1.6 \\
15 & 6.8 & 6.4 & 0.2 \\
16 & 4.1 & 3.8 & 0.3 \\
17 & 1.6 & 1.2 & 0 \\
\hline
\end{tabular}

1.6 on the $17^{\text {th }}$ week. This was closely followed by the yield from trash mulched plots with similar yield trend which also occluded to 1.2 Tonnes/Ha on the $17^{\text {th }}$ week. The performance was low in plot without mulch cover. It got to a maximum value of 5.2 Tonnes/Ha on the $11^{\text {th }}$ week after planting and began to narrow down toward its lowest value of 0.3 Tonnes/Ha on the $16^{\text {th }}$ week. The plant practically dried up before the $17^{\text {th }}$ week and no fruit was harvested from this plot at the end of $17^{\text {th }}$ week.

The result of ash content analysis showed that crop grown under sawdust mulch cover had the highest ash content of $0.25 \mathrm{~kg}$ representing 15 per cent of the dry matter. That of trash mulch was $0.20 \mathrm{~kg}$ i.e. 10 per cent of dry matter and the lowest was recorded on plot without cover which was $0.17 \mathrm{~kg}$ representing less than 8.0 per cent of dry matter. This result shows that dry season okra performance was generally better under sawdust mulching.

\section{Conclusion}

From the analysis of soil moisture conservation obtained from the sawdust and trash mulch cover treatments, it could be concluded that sawdust will serve a good purpose as much as trash in mulching dry season vegetable farms in the Southwestern Nigeria. Since okra vegetative development under sawdust and trash mulch cover came out to be very close, it may be reasonable to conclude that sawdust will be a good alternative to trash mulching material for vegetable production particularly in the periurban vegetable gardening in Southwestern Nigeria where trash could be difficult to come by and synthetic mulching materials may attract additional overhead to the production cost in this sector of the economy. If adopted for soil moisture conservation in fallow fields, a sawdust quantity of 100 Tonnes/Ha is capable of reducing the rate of sawdust accumulation in sawmills around the region. Furthermore, introducing sawdust as a mulching material will disperse this waste over a wide area in various farms instead of allowing it to accumulate in localized spots in sawmills. A widespread use of sawdust on farmlands will induce bio-degradation of the waste and leaves little for burning.

\section{Recommendation}

Farmers adopting sawdust usage as mulching material should enjoy some incentive in form of carbon economic return. This is because the material will eventually find its way into the soil perhaps at the following tillage operation. This way a good quantum of carbon is locked up in the soil rather than being allowed to get into the atmosphere. This could spore a new carbon capture mechanism in the rural areas of Southwestern Nigeria.

\section{REFERENCES}

[1] F. Greenshare, "Improving Soil for Vegetable Gardening," 2013.

[2] D. C. Sanders, "Vegetable Crop Irrigation,” 2013. www.ces.ncsu.edu

[3] Africa STI, "IITA Releases Data on Disastrous Nigeria Rainfall,” 2013. www.africasti.com/environment.news

[4] Mongabey, "Nigeria Climate," 2013. www.mangabey.com/history/nigeria-climate.html

[5] R. G. Allen, L. S. Pereira, D. Raes and M. Smith, "Crop Evapotranspiration Guidelines for Computing Crop Water Requirement,” FAO Irrigation and Drainage Paper 56, FAO, Rome, 1998, p. 21.

[6] Bill and Melinda Gate Foundation, "Good Seed, Better Lives for Poor Farmers,” 2013. www.gatefoundation.org/agric.development.htm

[7] IOL News, "Poor Farming Technologies Leaves Africa Hungry,” 2013. www.iol.co.za/news/africa.html

[8] IFAD, “African Women Farmers' Need for Suitable Tools," 2013.

[9] C. Aja, “Tomato, Nutritious Vegetables,” 2012.

[10] A. A. Eneta and U. E. Okon, "Economics of Water Leaf Production in Akwa Ibom State Nigeria,” J. Field Actions, Vol. 4, 2010. www.factsreports.revenues.org

[11] NAN, "Farmers Prepare for Dry Season Farming," 2013. www.nannewsngr.com

[12] Global Food Security, "Fadama III Rural Agriculture Project Fast Becoming a Household name in Nigeria," 2013.

[13] K. C. Hansen, "Mulching for Healthy Plants, Water Conservation,” East Texas Gardening,” 2013.

[14] B. R. Lerner, "Mulching Conserves Soil Moisture,” Purdue University Consumer Horticulture, 1992. www.hort.purdue.edu

[15] R. Bhatt, "Moisture Conservation and Productivity of Rainfed Maize as Affected by Tillage and Different Modes of Straw Mulch Application in Foothills of Shivaliks,” 2013

[16] Curbby, “48 Different Mulching Materials,” 2013.

[17] Better Vegetable Gardening, "Types of Mulching Materi- 
als for Vegetable Gardening,” 2013.

www.bettervegetablegardening.com

[18] D. O. Adefolalu, "Precipitation Trends, Evapotranspiration and the Ecological Zones of Nigeria," Journal of Theoretical and Applied Climatology, Vol. 39, No. 2, 1998, pp. 81-89.

[19] D. Maduka, "SRADev Nigeria Begins Waste to Wealth Sawdust Project,” Nigeria Tribune, 2011.

[20] UNFCCC, "Oko-Baba Sawdust Waste to Wealth Initiative,” 2013.

Unfccc.int/secretariat/momentum_for_change/news/7150. php

[21] UNDP, “Nigeria's Sawdust Recycling Creates Jobs While Cleaning Up City,” 2013.

[22] PfPI, "Biomass Basics. Partnership for Policy Integrity Publications (PFPI),” 2013.
[23] "Carbon Emissions from Burning Biomass for Energy. Partnership for Policy Integrity Publications (PFPI)," 2013.

[24] Chimney Sweep, “Wood Burning Basics,” 2013.

[25] S. Carty, "Firewood Alternatives. eHow," 2013. www.ehow.com/way

[26] RSC, “Carbon Capture with Sawdust,” 2011. www.rsc.org/chemistryworld/news

[27] A. Aston, “Capturing Carbon with Sawdust,” Global CCS Institute, 2011.

[28] Political Ecology, “Carbon Capture with Sawdust,” 2013.

[29] M. Beck, "Mulching for Enhanced Low Cost, Low Maintenance Landscapes,” Aggic Horticulture, 2013. 